\title{
ALK gene amplification is associated with poor prognosis in colorectal carcinoma
}

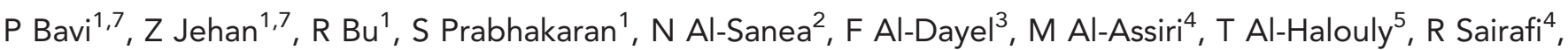 \\ S Uddin ${ }^{1}$ and K S Al-Kuraya*,1,6 \\ ${ }^{1}$ Human Cancer Genomic Research, Research Center, King Faisal Specialist Hospital and Research Center, Riyadh 11211, Saudi \\ Arabia; ${ }^{2}$ Colorectal Unit, Department of Surgery, King Faisal Specialist Hospital and Research Center, Riyadh 11211, Saudi Arabia; \\ ${ }^{3}$ Department of Pathology, King Faisal Specialist Hospital and Research Center, Riyadh 11211, Saudi Arabia; ${ }^{4}$ Department of \\ Surgery, Security Forces Hospital, Riyadh, Saudi Arabia; ${ }^{5}$ Department of Pathology, Security Forces Hospital, Riyadh, Saudi Arabia \\ and ${ }^{6}$ Department of Pathology, College of Medicine, Alfaisal University, Riyadh, Saudi Arabia
}

Background: Recently, the anaplastic lymphoma kinase (ALK) has been found to be altered in several solid and haematological tumours. ALK gene copy number changes and mutations in colorectal cancers (CRCs) are not well characterised. We aimed to study the prevalence of ALK copy number changes, translocations, gene mutations and protein expression in 770 CRC patients, and correlate these findings with molecular and clinico-pathological data.

Methods: ALK gene copy number variations and ALK expression were evaluated by fluorescence in situ hybridisation (FISH) and immunohistochemistry, respectively.

Results: Translocations of the ALK gene were not observed; 3.4\% (26 out of 756) of the CRC patients tested had an increase in $A L K$ gene copy number either amplification or gain. Interestingly, increased ALK gene copy number alteration was associated with poor prognosis $(P=0.0135)$ and was an independent prognostic marker in multivariate Cox proportional hazards model. The study reveals a significant impact of ALK gene copy number alterations on the outcome of patients with CRC.

Conclusion: The findings of our study highlight a potential role of targeting ALK in advanced CRCs by using ALK FISH and ALK $I \mathrm{HC}$ as a screening tool to detect ALK alterations. Based on these findings, a potential role of ALK inhibitor as a therapeutic agent in a subset of CRC merits further investigation.

Colorectal cancer (CRC) is a cause of high morbidity and mortality worldwide. The incidence of CRC in Saudi Arabia is rising despite significant advances in the management of CRC. According to the Saudi Cancer Registry, it is the most common cancer in males across all ages in Saudi Arabia (Al-Eid and Manalo, 2007). Identification of a new targeted therapy that allows progress in the management of CRC and improves survival is warranted.

Anaplastic lymphoma kinase (ALK) is a tyrosine kinase that was first identified as part of chromosomal rearrangement as a fusion partner of nucleophosmin (Morris et al, 1994). Other fusion partners to ALK such as KIF5B (Takeuchi et al, 2009), NPM1
(Morris et al, 1994), RET (Takeuchi et al, 2012), ROS (Takeuchi et al, 2012), VCL (Debelenko et al, 2011) and TFG (Hernandez et al, 1999) genes have also been described. The products of these fusion proteins have lead to constitutively activated ALK tyrosine kinase (Morris et al, 1994; Griffin et al, 1999; Hernandez et al, 1999; Lamant et al, 1999; Lawrence et al, 2000; Bridge et al, 2001; Debelenko et al, 2003; Debiec-Rychter et al, 2003; Gascoyne et al, 2003; Lamant et al, 2003; Ma et al, 2003; Armstrong et al, 2007; Soda et al, 2007; Debelenko et al, 2011; Takeuchi et al, 2011). Furthermore, many recent reports have shown that the ALK kinase is constitutively activated by additional mechanisms such as

\footnotetext{
*Correspondence: Professor KS Al-Kuraya; E-mail: Kkuraya@kfshrc.edu.sa
}

${ }^{7}$ These authors contributed equally to this paper.

Received 22 May 2013; revised 14 September 2013; accepted 23 September 2013; published online 15 October 2013 
activating mutations (Chen et al, 2008; George et al, 2008; Janoueix-Lerosey et al, 2008) and ALK gene amplification (Salido et al, 2011; Tuma, 2012; van Gaal et al, 2012).

The discovery of $A L K$ gene dysregulation and its potential utility as a biomarker in many solid tumours such as inflammatory myofibroblastic tumours (Griffin et al, 1999; Panagopoulos et al, 2006), oesophageal squamous cell carcinoma (Jazii et al, 2006; Du et al, 2007), breast carcinoma (Tuma, 2012), lung adenocarcinoma (Salido et al, 2011; Takeuchi et al, 2012), paediatric renal cell carcinoma (Debelenko et al, 2011) and ovarian cancer (Jazii et al, 2006; Du et al, 2007) have led to the development of ALK inhibitors with promising results in preclinical models and early clinical trials (Panagopoulos et al, 2006; Corao et al, 2009; Katayama et al, 2011; Grob et al, 2012; La Madrid et al, 2012; Sugawara et al, 2012; Tuma, 2012). Two recent studies have detected EML4 and C2orf44 as fusion partners of ALK in CRC (Lin et al, 2009; Lipson et al, 2012). This has prompted us to study the potential role of $A L K$ gene alterations in a very large cohort of CRC in Saudi Arabian patients. In addition, mutations in KRAS and BRAF are known to influence response to treatment. Therefore, an attempt was also made to investigate the microsatellite instability (MSI) and mutational status of these genes to study their correlation with ALK alterations in CRC.

In this work, we sought to perform detailed analysis of $A L K$ gene copy number, rearrangement and mutation, as well as expression pattern of ALK. We then correlated ALK alterations with clinical data including survival analysis, pathological parameters and key molecular alterations in CRC.

\section{MATERIALS AND METHODS}

Patients selection and TMA construction. A total of 770 patients with CRC diagnosed between 1990 and 2011 were randomly selected from King Faisal Specialist Hospital and Research Centre (KFSHRC) and Security Forces Hospital, Riyadh. A colorectal progression tissue microarray (TMA) that represents the entire spectrum of lesions in colorectal carcinogenesis was constructed comprising 770 CRC samples, 229 adjacent normal colorectal mucosa, 24 adenoma and 47 lymph node metastasis as described previously (Bavi et al, 2010). Clinical and histopathological data were available for all these patients. Patients with colon cancer underwent surgical colonic resection and those with rectal cancer underwent anterior resection or abdominoperineal resection. All node-positive colon cancers received 5-fluorouracil-based adjuvant chemotherapy. A vast majority of the rectal cancers received radiotherapy alone or chemoradiotherapy before surgery, followed by adjuvant chemotherapy after surgery. Colorectal Unit, Department of Surgery (KFSHRC and Security Forces Hospital), provided long-term follow-up data about the date and cause of death for this cohort of patients. Follow-up was calculated from the date of resection of the primary tumour, and all surviving cases were censored for survival analysis on 31 December 2011. Two pathologists (PB and SP) reviewed all tumours for grade and histological subtype. The institutional review board of the KFSHRC approved the study.

ALK expression analysis (immunohistochemistry). As described earlier, TMA slides were processed and stained manually (Bavi et al, 2011b). Primary ALK antibody (clone D5F3; CST; 1:100 dilution; Dako Target Retrieval, $\mathrm{pH}$ 9) was applied and incubated overnight. Antigen-antibody reaction was visualised by an enhanced polymer-based detection system, Envision Plus duallink System-HRP, for $1 \mathrm{~h}$. Diaminobenzidene (DAB +; Dako, Glostrup, Denmark) was used for $5 \mathrm{~min}$ as the chromogen. The positive control was from a known CD30-positive ALCL case. The negative control was a mouse immunoglobulin G1 serum substitution for the primary antibody (ALK). Earlier reports have shown that ALK protein expression is always lower in ALKrearranged lung adenocarcinomas $(1: 100)$ relative to ALK-rearranged ALCLs $(1: 1000)$. (Mino-Kenudson et al, 2010). Taking into consideration the limitation of using ALCL as a positive control because of high concentration of ALK protein epitopes as compared with solid tumours, we used a lower dilution of the ALK antibody $(1: 100)$ to ensure optimal detection of low concentration of the ALK protein in CRC.

Two pathologists (PB and SP) performed immunohistochemistry (IHC) scoring to determine a $\mathrm{H}$ score as reported earlier (Thunnissen et al, 2012), and consensus was established by reviewing the slides together in the case of discrepant scores. A final $\mathrm{H}$ score (range 0-300) was obtained by adding the sum of scores obtained for each intensity and proportion of area stained (Abubaker et al, 2009). X-tile plots were constructed for assessment of biomarker and optimisation of cutoff points based on outcome as has been described earlier (Camp et al, 2004). Colorectal cancers were grouped into two groups based on X-tile plots: one with complete absence $(\mathrm{H}$ score $=0)$ and the other group with ALK expression ( $\mathrm{H}$ score $>0$ ), depending on the $\mathrm{H}$ score.

Fluorescence in situ hybridisation. Fluorescence in situ hybridization (FISH) assay for $A L K$ gene rearrangement and amplification was performed on a TMA (Bavi et al, 2011a). Bacterial artificial chromosome (BAC) corresponding to $A L K$ gene was utilised to analyse copy number variation. The BAC clone was selected by browsing Ensembl Genome Browser http://ensembl.org/. Bacterial artificial chromosome RP11-328L16 corresponding to the ALK gene were purchased from Children's Hospital Oakland Research Institute (Oakland, CA, USA). The BAC clone was cultured, DNA was isolated and labelled with Digoxygenin using the DNA labelling kit from Roche (Hamburg, Germany). A commercially available centromeric probe for chromosome2 CEP2 (Abbott Molecular, Des Plaines, IL, USA) was utilised as an internal control. Centromere 2 was selected as a reference gene to rule out polyploidy based on earlier reports, which indicate that background numeric aberrations affecting chromosome 2 in CRC are very rare (Rooney et al, 2001; Carvalho et al, 2009; Beroukhim et al, 2010). Fluorescence in situ hybridization on CRC TMA was performed as previously described (Jehan et al, 2009). Tissue samples were classified with an ALK/centromere 2 ratio of 1.0 as normal; between 1.0 and 2.0 as having ALK gains; and 2.5 and above as amplified (Salido et al, 2011). A minimum of 50 cells were scored for the presence of both centromeric and ALK signals.

Fluorescence in situ hybridisation assay for the $A L K$ gene rearrangement was performed on the CRC TMA slides with the use of an ALK break-apart probe set obtained from Vysis LSI ALK Dual break-apart rearrangement probe (Abbott Molecular). The slides were pre-processed with a paraffin pre-treatment reagent kit. The FISH assays were performed according to the manufacturer's instructions. The occurrence of an ALK rearrangement (ALK FISH positive) was concluded if $>15 \%$ of tumour cells showed split red and green signals and/or single red signals in addition to a singlefused signal; otherwise, the specimen was classified as ALK FISH negative (Kwak et al, 2010). A positive and negative slide for rearrangement available from Vysis (Abbott Molecular) were used as controls. Increase in the number of fused signals were considered to be amplifications and gains. A minimum of 50 cells per sample were scored for ALK rearrangement.

DNA isolation. DNA was extracted from paraffin-embedded CRC tissues using Gentra DNA isolation kit (Gentra, Minneapolis, $\mathrm{MN}$, USA) following the manufacturer's recommendations as described previously (Abubaker et al, 2008).

Quantitative real-time PCR. Further confirmation of FISH results were done by quantitative PCR (qPCR). DNA from formalin-fixed, paraffin-embedded samples of colon cancer with 
normal and increased ALK copy number by FISH were selected for validation by quantitative real-time (qRT) PCR. DNA content was normalised to that of long interspersed elements (LINE1), a repetitive element for which copy number per haploid genome is similar in both the normal DNA sample and DNA from cancer cells. Primers were designed by Primer express 3.0 software (Applied Biosystems, Foster City, CA, USA) to hybridise to sequences of genomic DNA for ALK. The primers to the genomic sequences were ALK and LINE1, and are provided in Supplementary Table 1 (Jehan et al, 2008). The PCR conditions and Light Cycler PCR protocol were as previously described (Abubaker et al, 2009). The Pfaffle method for relative quantification was used to calculate the fold change for colon cancer samples that showed normal copy number and amplification of $A L K$ gene (Pfaffl et al, 2002). The relative copy number ratio of a target gene is calculated based on the efficiency and crossing point deviation of samples (normal) vs colon cancer, and is expressed in comparison with a reference gene (LINE1). For a normal cell, the copy number of a gene per haploid genome should be 1 .

PCR and DNA sequencing for ALK, KRAS and BRAF gene. ALK mutational analysis was performed on 101 CRC samples that have high expression of ALK protein by IHC. Primer express 3.0 software (Applied Biosystems) was used to design the primers for exons of tyrosine kinase domain (exons 20-28) and their flanking intronic sequences of $A L K$ gene (Supplementary Table 2); exon 1 of BRAF; exons 1 and 2 of KRAS (Supplementary Table 3). The PCR sequencing protocol for ALK was same as described with minor change in the annealing temperature being $60^{\circ} \mathrm{C}$ for $45 \mathrm{~s}$ (Abubaker et al, 2009). The samples were finally analysed on an ABI PRISM $3100 \times 1$ genetic analyzer (Applied Biosystems).

Microsatellite markers and analyses. Allelic imbalances were measured by performing microsatellite analysis on all matched normal and tumour tissue by PCR amplification. A reference panel of five pairs of microsatellite primers comprising two mononucleotide microsatellites (BAT25 and BAT26) and three dinucleotide microsatellites (DS123, D5S346 and D17S250) were used to determine tumour MSI status (Boland et al, 1998). Multiplex PCR was performed in a total volume of $25 \mu \mathrm{l}$ using $50 \mathrm{ng}$ of genomic DNA, $2.5 \mu \mathrm{l} 10 \times$ Taq buffer, $1.5 \mu \mathrm{l} \mathrm{MgCl}_{2}(25 \mathrm{~mm})$, $10 \mathrm{pmol}$ of fluorescent-labelled primers, $0.05 \mu \mathrm{ldNTP}(10 \mathrm{~mm})$ and $0.2 \mu \mathrm{l}$ Taq polymerase $\left(1 \mathrm{U}_{\mu} \mathrm{l}^{-1}\right.$; all reagents were obtained from Qiagen Inc., Valencia, CA, USA). PCR was performed using an MJ Research PTC-200 thermocycler (Bruno, QC, Canada).

Statistical analysis. The JMP 9.0 (SAS Institute Inc., Cary, NC, USA) software package was used for data analyses. Survival curves were generated using the Kaplan-Meier method, with significance evaluated using the Mantel-Cox log-rank test. Risk ratio was calculated using the Cox proportional hazard model in both univariate and multivariate analyses. The values of $P<0.05$ were considered statistically significant.

\section{RESULTS}

Clinico-pathological data. The characteristics of the $770 \mathrm{CRC}$ patients are summarised in Table 1. The median age at the time of surgery was 57 years (interquartile range (IQR) 47.7-68.0 years). The median length of follow-up available for surviving patients was 43.0 months (IQR 20-65 months). The overall median 5-year overall survival for the study population was 35 months (IQR 15-60 months).

ALK protein expression by IHC. One hundred and three cases out of 703 representative cases were positive by IHC, representing $14.6 \%$ of all cases studied by IHC. Anaplastic lymphoma kinase IHC expression was non-informative in 67 (8.7\%) TMA spots

\begin{tabular}{|c|c|}
\hline \multicolumn{2}{|l|}{ Age } \\
\hline $\begin{array}{l}\text { Median } \\
\text { Range (IQR) }\end{array}$ & $\begin{array}{c}57.0 \\
47.7-68.0\end{array}$ \\
\hline \multicolumn{2}{|l|}{ Gender } \\
\hline $\begin{array}{l}\text { Male } \\
\text { Female }\end{array}$ & $\begin{array}{l}401(52.0) \\
369(48.0)\end{array}$ \\
\hline \multicolumn{2}{|l|}{ Status } \\
\hline $\begin{array}{l}\text { Alive } \\
\text { Dead } \\
\text { Unknown }\end{array}$ & $\begin{array}{c}574(74.5) \\
179(23.2) \\
17(2.2)\end{array}$ \\
\hline \multicolumn{2}{|l|}{ Histological type } \\
\hline $\begin{array}{l}\text { Adenocarcinoma } \\
\text { Mucinous carcinoma }\end{array}$ & $\begin{array}{r}685(88.9) \\
85(11.1)\end{array}$ \\
\hline \multicolumn{2}{|l|}{ Histological grade } \\
\hline $\begin{array}{l}\text { Well differentiated } \\
\text { Moderately differentiated } \\
\text { Poorly differentiated }\end{array}$ & $\begin{aligned} & 75(9.7) \\
& 601(78.1) \\
& 94(12.2)\end{aligned}$ \\
\hline \multicolumn{2}{|l|}{ Tumour site } \\
\hline $\begin{array}{l}\text { Left } \\
\text { Right } \\
\text { Unknown }\end{array}$ & $\begin{array}{c}612(79.5) \\
123(16.0) \\
35(4.5)\end{array}$ \\
\hline \multicolumn{2}{|l|}{ AJCC stage } \\
\hline $\begin{array}{l}\text { I } \\
\text { II } \\
\text { III } \\
\text { IV } \\
\text { Unknown }\end{array}$ & $\begin{array}{r}89(12.2) \\
257(35.3) \\
292(40.1) \\
90(12.4) \\
42(5.5)\end{array}$ \\
\hline \multicolumn{2}{|c|}{ Survival duration in months } \\
\hline $\begin{array}{l}\text { Median } \\
\text { Range }(\mathrm{IQR})^{\mathrm{a}}\end{array}$ & $\begin{array}{c}35.0 \\
15-60\end{array}$ \\
\hline
\end{tabular}

mainly because of the loss of tissue core during processing of the slide or because of the TMA spot being non-representative of tumour. The staining pattern ranged from an intense $3+$ staining in the cytoplasm and/or membrane (Figure 1A and B) to $2+$ moderate cytoplasmic staining and $1+$ faint cytoplasmic staining (Figure 1-E). A small subset of CRC tumours showed punctate coarse granular cytoplasmic staining seen in $1.4 \%$ (10 out of 703 ) of the CRC spots and was observed in $20-100 \%$ of the tumour cells in each spot. Anaplastic lymphoma kinase expression was not observed in the 300 normal colorectal mucosa. However, 29.2\% (7 out of 24) of adenomas analysed showed ALK expression, thereby indicating that altered ALK expression is a potential early event in colorectal carcinogenesis.

ALK copy number alterations and translocations. In our series of 770 CRC samples, 756 were analysable by FISH utilising the BAC probe RP11-328L16, as well as the ALK rearrangement probe. Fourteen TMA spots (1.8\%) were non-representative either because of lack of tumour or absence of tissue spot. Of the spots analysed, 20 cases (2.6\%) showed amplification of ALK gene (Figure $2 \mathrm{~A}$ and $\mathrm{C}$ ). No high level amplification of $A L K$ gene was observed in these 20 samples. We found ALK copy number gains 


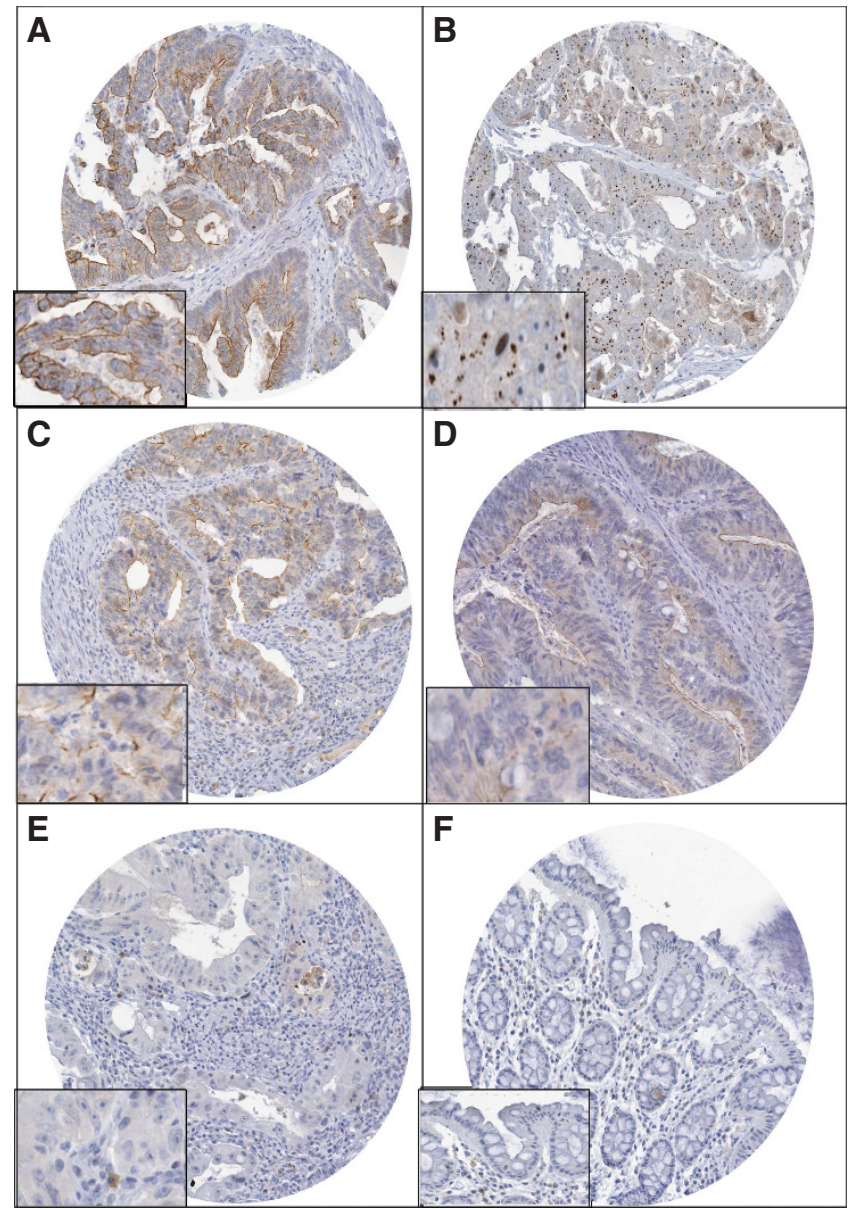

Figure 1. Tissue microarray based immunohistochemical analysis of ALK in CRC patients. An IHC H score was assigned to each case according to the following criteria: $3+$, intense, cytoplasmic and/or granular staining; $2+$, moderate, smooth cytoplasmic staining; $1+$, faint cytoplasmic staining; and 0 , no staining and the proportion of the tumour staining for that intensity was recorded as $5 \%$ increments from a range of $0-100$. (A) CRC array spot showing ALK overexpression with membranous staining. (B) A CRC array spot showing ALK overexpression with strong, granular cytoplasmic staining $(3+)$. (C) A CRC array spot showing ALK overexpression with moderate cytoplasmic staining( $2+$ ). (D) A CRC array spot showing low cytoplasmic expression of ALK $(1+)$. (E) Colorectal cancer tissue array spots with no cytoplasmic expression of ALK (0). (F) Normal colon tissue array spots showing no expression of ALK (0). All figures had $\times 10$ magnified image captured with an Aperio ScanScope XT (Aperio Technologies, Vista, CA, USA; objective insets: magnified view $\times 40$ magnified image).

in six $(0.8 \%)$ cases and none of them showed polysomy. In the majority of these cases, gains in $A L K$ gene were seen in at least $30 \%$ of the tumour cells. Colorectal cancer cases with either amplification or gain in $A L K$ gene were combined in one subgroup and referred to ALK amplification/gain. Table 2 lists the clinicopathological correlation of these CRC patients with ALK amplification/gain. We did not observe any $A L K$ gene amplification or gain in copy number in colorectal adenomas or normal colorectal mucosa. The FISH findings were further confirmed by qPCR analysis on a few selected amplified and non-amplified CRC samples (Figure 2E). We investigated the presence of EML4 fusion with ALK and found no translocation of these two genes. Analysis of other uncommon fusion genes such as TFG and KIF5B, which have been previously reported in lung cancer, were not investigated (Shinmura et al, 2008; Takeuchi et al, 2009).
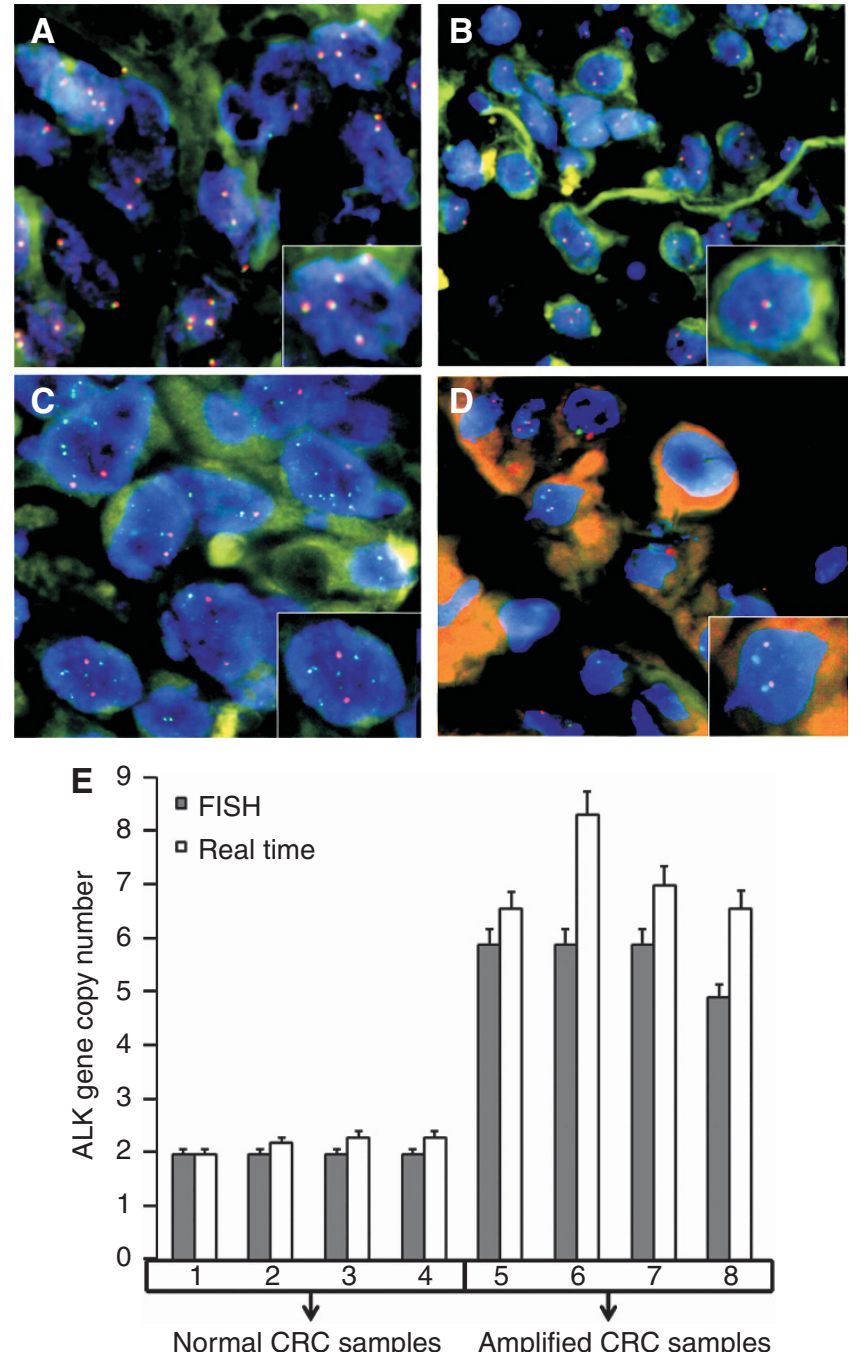

Figure 2. Determination of $A L K$ gene copy number by flourescence in situ hybridization (FISH) and qPCR in ALK-amplified and ALKnon-amplified CRC samples. A minimum of 20 cells with both the centromeric and ALK gene signals were scored to give conclusive data. (A) Colorectal cancer ALK-amplified sample hybridised with ALK breakapart probe showing six red and green fused signals (inset showing a single cell with amplification). (B) Colorectal cancer ALK-non-amplified sample hybridised with ALK break-apart probe showing normal tissue with two red and green fused signals (inset showing a single cell). (C) Colorectal cancer ALK-amplified sample hybridised with BAC probe RP11-328L16 and CEP2 probe showing two red CEP2 signals and 5-6 green signals representing the ALK gene amplification (inset showing a single cell with amplification). (D) Colorectal cancer ALKnon-amplified sample hybridised with BAC probe RP11-328L16 and CEP2 probe showing two red CEP2 signals and two green signals representing normal ALK copy number (inset showing a single cell). ( $\times$ 20/0.70 objective on an Olympus BX 51 microscope (Olympus America Inc, Center Valley, PA, USA) with the inset showing a $\times 40 / 0.85$ aperture magnified view of the same for Figure 1A-C). (E) Verification of the ALK gene copy number by qRTPCR. Histogram showing ALK gene copy number obtained from normal colon samples1-4 with two normal copies of ALK gene, and samples 5-8 are amplified colon cancer samples.

Correlation of $A L K$ gene copy number alteration and clinicopathological features. The number of cases that were overlapping with FISH and immunohistochemical analysis for ALK gene was 697, that is, data were available for both IHC and FISH in 697 
Table 2. Correlation of ALK (FISH) gene amplification and gain in copy number with clinico-pathological parameters in colorectal carcinoma

\begin{tabular}{|c|c|c|c|c|c|c|c|}
\hline & \multicolumn{2}{|c|}{ Total } & \multicolumn{2}{|c|}{ ALK-amplified + gain } & \multicolumn{2}{|c|}{ ALK normal } & \multirow{2}{*}{$P$-value } \\
\hline & $\mathbf{N}$ & $\%$ & $\mathbf{N}$ & $\%$ & $\boldsymbol{N}$ & $\%$ & \\
\hline $\begin{array}{l}\text { Total number of } \\
\text { cases }\end{array}$ & 756 & & 26 & 3.5 & 730 & 96.5 & \\
\hline \multicolumn{8}{|l|}{ Age } \\
\hline $\begin{array}{l}<50 \text { years } \\
>50 \text { years }\end{array}$ & $\begin{array}{l}218 \\
538\end{array}$ & $\begin{array}{l}28.8 \\
71.2\end{array}$ & $\begin{array}{r}6 \\
20\end{array}$ & $\begin{array}{l}2.7 \\
3.7\end{array}$ & $\begin{array}{l}212 \\
518\end{array}$ & $\begin{array}{l}97.3 \\
96.3\end{array}$ & 0.5003 \\
\hline \multicolumn{8}{|l|}{ Sex } \\
\hline $\begin{array}{l}\text { Male } \\
\text { Female }\end{array}$ & $\begin{array}{l}393 \\
363\end{array}$ & $\begin{array}{l}52.0 \\
48.0\end{array}$ & $\begin{array}{l}13 \\
13\end{array}$ & $\begin{array}{l}3.3 \\
3.6\end{array}$ & $\begin{array}{l}380 \\
350\end{array}$ & $\begin{array}{l}96.7 \\
96.4\end{array}$ & 0.8368 \\
\hline \multicolumn{8}{|l|}{ Tumour site ${ }^{a}$} \\
\hline $\begin{array}{l}\text { Left colon } \\
\text { Right colon }\end{array}$ & $\begin{array}{l}599 \\
122 \\
\end{array}$ & $\begin{array}{l}83.1 \\
16.9 \\
\end{array}$ & $\begin{array}{r}22 \\
3\end{array}$ & $\begin{array}{l}3.7 \\
2.5\end{array}$ & $\begin{array}{l}577 \\
119 \\
\end{array}$ & $\begin{array}{l}96.3 \\
97.5 \\
\end{array}$ & 0.4859 \\
\hline \multicolumn{8}{|l|}{ Histological type } \\
\hline $\begin{array}{l}\text { Adenocarcinoma } \\
\text { Mucinous carcinoma }\end{array}$ & $\begin{array}{r}673 \\
83\end{array}$ & $\begin{array}{l}89.0 \\
11.0\end{array}$ & $\begin{array}{r}25 \\
1\end{array}$ & $\begin{array}{l}3.7 \\
1.2\end{array}$ & $\begin{array}{r}648 \\
82\end{array}$ & $\begin{array}{l}96.3 \\
98.8\end{array}$ & 0.1792 \\
\hline \multicolumn{8}{|l|}{ Tumour stage $^{a}$} \\
\hline $\begin{array}{l}\text { I } \\
\text { II } \\
\text { III } \\
\text { IV }\end{array}$ & $\begin{array}{r}89 \\
250 \\
281 \\
94\end{array}$ & $\begin{array}{l}12.5 \\
35.0 \\
39.4 \\
13.2\end{array}$ & $\begin{array}{l}4 \\
9 \\
7 \\
3\end{array}$ & $\begin{array}{l}4.5 \\
3.6 \\
2.5 \\
3.2\end{array}$ & $\begin{array}{r}85 \\
241 \\
274 \\
91\end{array}$ & $\begin{array}{l}95.5 \\
96.4 \\
97.5 \\
96.8\end{array}$ & 0.7904 \\
\hline
\end{tabular}

\section{Differentiation ${ }^{a}$}

\begin{tabular}{|c|c|c|c|c|c|c|c|}
\hline Well/moderate & 656 & 87.6 & 21 & 3.2 & 635 & 96.8 & 0.3142 \\
\hline Poor & 93 & 12.4 & 5 & 5.4 & 88 & 94.6 & \\
\hline
\end{tabular}

\section{ALK IHC}

\begin{tabular}{|c|c|c|c|c|c|c|c|}
\hline High & 100 & 14.3 & 4 & 4.0 & 96 & 96.0 & 0.8130 \\
\hline Low & 597 & 85.7 & 21 & 3.5 & 576 & 96.5 & \\
\hline
\end{tabular}

\section{P53 mutation ${ }^{\mathrm{a}}$}

\begin{tabular}{|c|c|c|c|c|c|c|c|}
\hline $\begin{array}{l}\text { Positive } \\
\text { Negative }\end{array}$ & $\begin{array}{l}181 \\
397\end{array}$ & $\begin{array}{l}31.3 \\
68.7\end{array}$ & $\begin{array}{r}5 \\
13\end{array}$ & $\begin{array}{l}2.8 \\
3.3\end{array}$ & $\begin{array}{l}176 \\
384\end{array}$ & $\begin{array}{l}97.2 \\
96.7\end{array}$ & 0.7397 \\
\hline \multicolumn{8}{|c|}{ Braf mutation ${ }^{a}$} \\
\hline $\begin{array}{l}\text { Positive } \\
\text { Negative }\end{array}$ & $\begin{array}{r}17 \\
689\end{array}$ & $\begin{array}{r}2.4 \\
97.6\end{array}$ & $\begin{array}{r}1 \\
23\end{array}$ & $\begin{array}{l}5.9 \\
3.3\end{array}$ & $\begin{array}{r}16 \\
666\end{array}$ & $\begin{array}{l}94.1 \\
96.7\end{array}$ & 0.6024 \\
\hline \multicolumn{8}{|c|}{ Kras mutation ${ }^{a}$} \\
\hline $\begin{array}{l}\text { Positive } \\
\text { Negative }\end{array}$ & $\begin{array}{l}198 \\
508\end{array}$ & $\begin{array}{l}28.0 \\
72.0\end{array}$ & $\begin{array}{r}6 \\
18\end{array}$ & $\begin{array}{l}3.0 \\
3.5\end{array}$ & $\begin{array}{l}192 \\
490\end{array}$ & $\begin{array}{l}97.0 \\
96.5\end{array}$ & 0.7325 \\
\hline \multicolumn{8}{|c|}{ MSI-molecular ${ }^{a}$} \\
\hline $\begin{array}{l}\text { MSI-H } \\
\text { MSI-S/L }\end{array}$ & $\begin{array}{r}83 \\
642 \\
\end{array}$ & $\begin{array}{l}11.4 \\
88.6\end{array}$ & $\begin{array}{r}5 \\
20 \\
\end{array}$ & $\begin{array}{l}6.0 \\
3.1 \\
\end{array}$ & $\begin{array}{r}78 \\
622 \\
\end{array}$ & $\begin{array}{l}94.0 \\
96.9 \\
\end{array}$ & 0.2086 \\
\hline \multicolumn{8}{|c|}{ Overall survival } \\
\hline 5 Years & - & - & - & 53.5 & - & 70.9 & 0.0135 \\
\hline
\end{tabular}



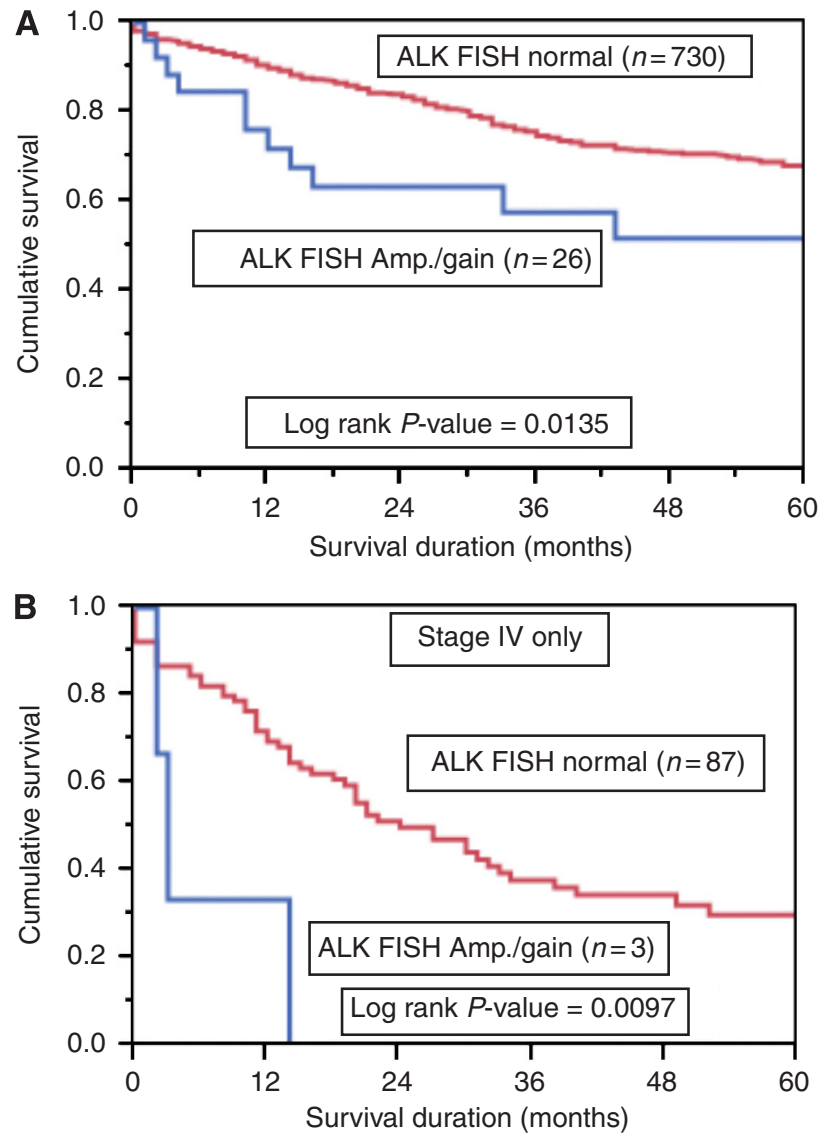

Figure 3. Prognostic significance of ALK in CRC and the Kaplan-Meier survival analysis. (A) Colorectal cancer patients with FISH amplification/ gain and increased copy number had reduced overall survival of $53.5 \%$ at 5 years compared with $70.9 \%$ with normal FISH $(P=0.0135)$. (B) In stage IV CRC, patients with FISH gain/amplification and increased copy number had reduced median overall survival of 3 months as compared with a median survival of 27 months with normal FISH $(P=0.0097)$.

TMA spots. Although $A L K$ gene amplification did not correlate with ALK protein expression in all CRC samples $(P=0.8130)$, a good concordance was observed between $A L K$ gene copy number and ALK expression $(P=0.0246)$ in advanced CRC subgroup: Stage III-IV CRC subgroup. In addition, $A L K$ gene amplification alone was significantly associated with poor tumour differentiation (Supplementary Table 4) in advanced CRC subgroup: Stage IV $(P=0.0233)$. However, there were only three samples in Stage IV CRC subgroup that showed ALK amplification/gain in advanced CRC subgroup: Stage IV. In all CRC samples, ALK amplification and ALK gain did not show any association with age $(P=0.5003)$, gender $(P=0.8368)$, histology subtype $(P=0.1792)$, tumour grade $(P=0.3142)$ and stage $(P=0.7904$; Table 2$)$.

ALK mutations. Although ALK expression was seen in 103 samples, 2 samples did not have sufficient DNA and 101 CRC samples were analysed for ALK mutations. One heterozygous missense mutation was detected in the $A L K$ gene among the 101 CRC samples that showed ALK expression. This mutation at base 3421, a G > A substitution, was seen in exon 21 and located in the tyrosine kinase domain region. This resulted in an amino-acid change from an aspartic acid to an asparagine residue at codon 1141 (Supplementary Figure 1). This is a novel mutation and we further investigated whether this was a somatic or a germline mutation. DNA from corresponding normal colon from this patient was again analysed for the presence of this mutation.

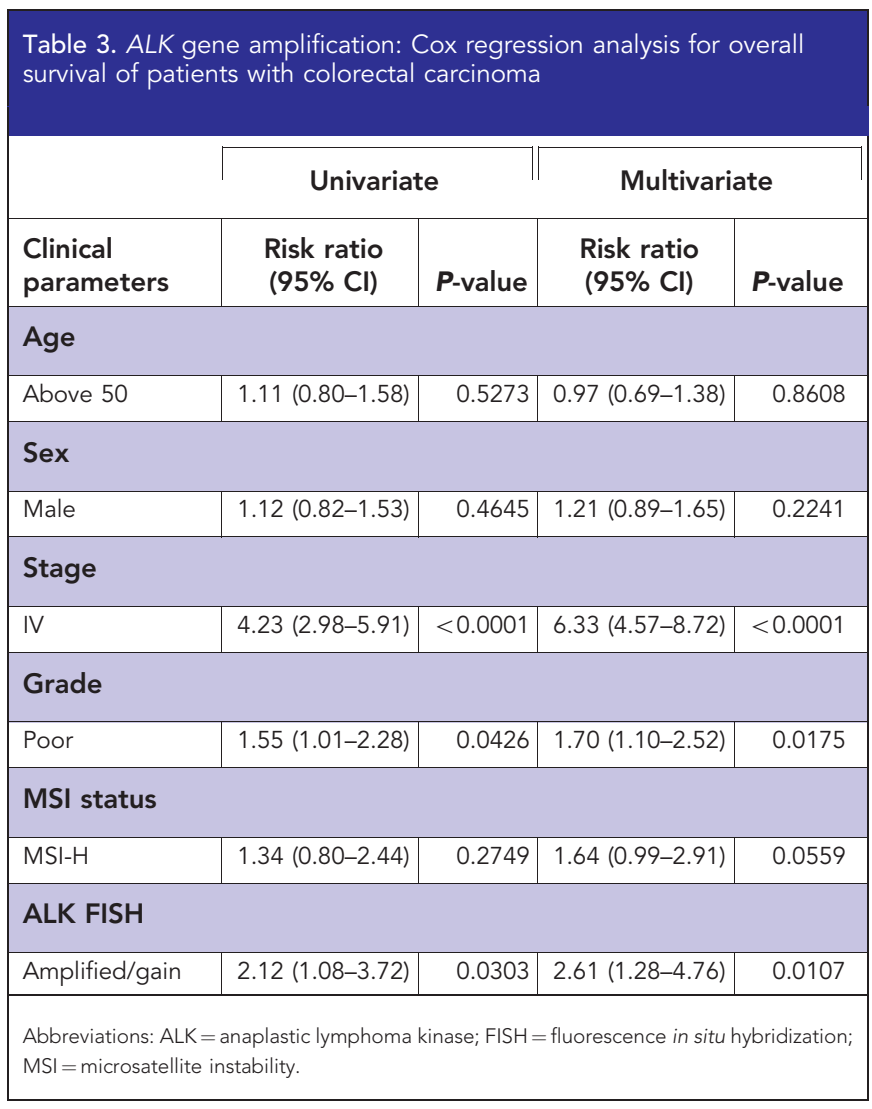

Presence of the same novel mutation in the normal tissue confirmed that this mutation is a germline mutation. Although germline mutations of $A L K$ gene have been previously identified in familial neuroblastoma, family history was negative in this CRC patient. This patient with an activating germline mutation was a male patient with a Stage II, moderately differentiated adenocarcinoma on the left side with a negative family history, and showed ALK expression that was both cytoplasmic and membranous. However, there was lack of $A L K$ gene amplification or gain in copy number.

KRAS and BRAF gene mutation analysis. Analysis of the common altered known gene mutations in CRC were analysed and we studied their correlations with $A L K$ gene alteration. A total of 717 of the CRC samples included in this study had been analysed for KRAS and BRAF mutations. We found BRAF mutations in only 17 out of 717 (2.3\%) CRC samples, whereas KRAS mutation was found in 201 out of 717 CRC samples (28.0\%). Microsatellite instability analysis data was available in 741 samples, and the incidence of MSI-H, microsatellite low and microsatellite stable was $11.2 \%$ (83 out of 741 ), $18.6 \%$ (138 out of 741 ) and $70.2 \%$ (520 out of 741), respectively. A mutual exclusivity was observed between KRAS and BRAF mutations $(P=0.0183)$. No correlation was observed between present $A L K$ gene alteration and known oncogenic mutations in KRAS and BRAF genes or MSI status in CRC.

$A L K$ gene alteration and overall survival. The prognostic significance of $A L K$ gene amplification and ALK protein expression was analysed using the Kaplan-Meier method. The results showed that the prognosis was poor $(P=0.0135)$ in patients with $A L K$ gene amplification and gain in copy number as compared with CRC with normal $A L K$ gene copy number (Figure $3 \mathrm{~A}$ ). In the multivariate analysis using the Cox proportional hazard model (Table 3) for multiple factors such as age, gender, AJCC stage, MSI and tumour differentiation, the relative risk was 2.61 (for $A L K$ gene 
amplification and gain in copy number (95\% CI 1.28-4.76; $P=0.0107)$ and 6.33 for advanced AJCC stage $(95 \%$ CI $4.57-8.72 ; P<0.0001)$. Thus, $A L K$ gene amplification and gain in copy number was an independent prognostic marker for poor survival in CRC across all stages. We also assessed the overall survival of ALK-amplified/gain tumours in advanced Stage IV subgroup only. In Stage IV, CRC with ALK amplification/gain had a poor overall survival of only 3 months as compared with 27 months in CRC with normal copy number of $A L K$ gene $(P=0.0097)$.

\section{DISCUSSION}

Recent reports have shown that ALK tyrosine kinase receptor is a strong biomarker and a good therapeutic target for a significant number of cancer patients (Kelleher and McDermott, 2010; Grande et al, 2011). Because receptor tyrosine kinases may be activated in human malignancies by genomic amplification, chromosome translocation or point mutations (Blume-Jensen and Hunter, 2001), we sought to comprehensively analyse $A L K$ gene alteration in a large series of CRC. The goal of the present study was to identify the frequency and nature of ALK alterations and to determine whether there was a relationship between these alterations and clinico-pathological findings including clinical outcome. This was accomplished by screening 770 CRC patients treated at KFSHRC and Security Forces Hospital.

We identified increased $A L K$ gene copy number (amplification/ gain) in 26 out of 756 CRC samples, representing 3.4\% of all CRC samples studied, suggesting that ALK copy number increase characterise a small proportion of Saudi Arabian CRC. Furthermore, if we limit our analysis to advanced stage of CRC (Stage IV), ALK amplification showed significant association with poor differentiation, which is indicative of aggressive phenotype. Interestingly, patients harbouring ALK-increased copy number had a significant poor clinical outcome across all stages and also in advanced Stage IV subgroup only. Remarkably, this clinical outcome association was independent of age, gender, tumour stage, grade, histological subtype and MSI status in all CRC cases, thereby confirming that $A L K$ gene amplification/gain is an independent prognostic marker for poor survival in CRC.

Screening all colorectal carcinomas for the alterations in $A L K$ gene copy number would not be practical owing to the low frequency of ALK amplifications/gain observed. It may be more feasible to screen only the advanced clinical stage CRC to detect ALK amplifications that would benefit from the addition of ALK inhibitor. In contrast to earlier studies in which an excellent correlation was observed between ALK translocations and ALK expression, in colorectal carcinoma, increased ALK gene copy number does not translate to increased ALK protein expression, thereby resulting in poor correlation between ALK FISH and ALK IHC. At present, we do not fully understand this mechanism but propose possible mechanisms such as posttranscriptional silencing (Adjei, 2001; Del Grosso et al, 2011) cancer subtype and site-specific effects modulating ALK expression and other upstream regulator of ALK that could be having a role in this mechanism (Perez-Pinera et al, 2007; Palmer et al, 2009; Takagi et al, 2013). A similar lack of correlation has been reported in oesophageal cancer and pulmonary sarcomatoid carcinoma (Preusser et al, 2013; Schoppmann et al, 2013).

Existing techniques in the detection of ALK IHC protein and $A L K$ gene copy number alterations need to be refined as is evident from the elegant work done by Nitta et al (2013) who developed a dual bright-field assay for concurrent detection of ALK protein expression and $A L K$ gene rearrangement with much more sensitivity. Given the relative advantages and disadvantages of current ALK IHC and ALK FISH assays, testing of both types might be required for accurate ALK status evaluation in tumours. Recently, Sun et al (2012) have reported ALK inhibitor crizotinib to be responsive in a NSCL patient that was negative for ALK gene rearrangement but was positive for ALK expression by IHC. The possibility that crizotinib affected the MET or ROS1 pathways leading to responsiveness was ruled out by investigation of these genes and demonstrating lack of any aberrations (Sun et al, 2012). Considering these important findings, Stage IV CRC with ALK expression alone without $A L K$ gene amplification also may benefit from treatment with ALK inhibitors in future clinical trials.

C2orf44-ALK and EML4-ALK fusion (a novel variant novel variant E21;20) have been reported earlier in 2.5\% (1 out of 40) and $2.4 \%$ (2 out of 83) CRCs, respectively (Lin et al, 2009; Lipson et al, 2012). In this study, concurrent rearrangement of ALK/EML4 by FISH was negative, and we did not test for the rearrangement of other fusion partners to ALK such as C2orf44 (Lipson et al, 2012), KIF5B (Takeuchi et al, 2009), NPM1 (Morris et al, 1994), VCL (Debelenko et al, 2011) TFG (Hernandez et al, 1999), RET (Takeuchi et al, 2012), ROS (Takeuchi et al, 2012), VCL (Debelenko et al, 2011) and TFG (Hernandez et al, 1999). Therefore, a concurrent alteration of these loci cannot be excluded. To investigate the role of $A L K$ gene alterations other than structural rearrangements in colorectal carcinogenesis, we analysed 101 CRC samples for ALK mutations having ALK overexpression. Only one patient was found to have single-nucleotide heterozygous missense mutation at base 3421; a G>A substitution was seen in exon 21 and located in the tyrosine kinase domain region. The absence of ALK rearrangement together with the very low percentage of activating mutation in the ALK suggest that these alterations might not be relevant events in CRC.

In conclusion, ALK amplification and copy number gain is an important genetic change in CRC and is associated with poor patient outcome. The findings of our study highlight a potential role of targeting ALK in advanced CRCs by using ALK FISH and ALK IHC as a screening tool to detect ALK alterations. However, these findings need to be validated in future studies in which ALK alterations can be used to identify CRC subsets that can maximally benefit from ALK inhibitors.

\section{ACKNOWLEDGEMENTS}

We thank Valorie Balde, Padmanaban Annaiyappanaidu, Khadija Abdul Rahman Alobaisi, Wael Haqqawi, Hassan Al Dossarie, Mohsen Al Hazmi for their technical assistance, and Zeeshan Qadri for data analysis.

\section{CONFLICT OF INTEREST}

The authors declare no conflict of interest.

\section{REFERENCES}

Abubaker J, Bavi P, Al-Haqawi W, Sultana M, Al-Harbi S, Al-Sanea N, Abduljabbar A, Ashari LH, Alhomoud S, Al-Dayel F, Uddin S, Al-Kuraya KS (2009) Prognostic significance of alterations in KRAS isoforms KRAS-4A/4B and KRAS mutations in colorectal carcinoma. J Pathol 219: 435-445.

Abubaker J, Jehan Z, Bavi P, Sultana M, Al-Harbi S, Ibrahim M, Al-Nuaim A, Ahmed M, Amin T, Al-Fehaily M, Al-Sanea O, Al-Dayel F, Uddin S, Al-Kuraya KS (2008) Clinicopathological analysis of papillary thyroid cancer with PIK3CA alterations in a Middle Eastern population. $J$ Clin Endocrinol Metab 93: 611-618.

Adjei AA (2001) Blocking oncogenic Ras signaling for cancer therapy. J Natl Cancer Inst 93: 1062-1074. 
Al-Eid HS, Manalo MS (2007) Saudi Cancer Registry. Saudi Arabia Cancer Incidence and Survival Report 2007, A-ZA Bazarbashi S (ed.) King Faisal Specialist Hospital \& Research Centre: Riyadh, Saudi Arabia.

Armstrong F, Lamant L, Hieblot C, Delsol G, Touriol C (2007) TPM3-ALK expression induces changes in cytoskeleton organisation and confers higher metastatic capacities than other ALK fusion proteins. Eur J Cancer 43: 640-646.

Bavi P, Prabhakaran SE, Abubaker J, Qadri Z, George T, Al-Sanea N, Abduljabbar A, Ashari LH, Alhomoud S, Al-Dayel F, Hussain AR, Uddin S, Al-Kuraya KS (2010) Prognostic significance of TRAIL death receptors in Middle Eastern colorectal carcinomas and their correlation to oncogenic KRAS alterations. Mol Cancer 9: 203.

Bavi P, Uddin S, Ahmed M, Jehan Z, Bu R, Abubaker J, Sultana M, Al-Sanea N, Abduljabbar A, Ashari LH, Alhomoud S, Al-Dayel F, Prabhakaran S, Hussain AR, Al-Kuraya KS (2011a) Bortezomib stabilizes mitotic cyclins and prevents cell cycle progression via inhibition of UBE2C in colorectal carcinoma. Am J Pathol 178: 2109-2120.

Bavi P, Uddin S, Bu R, Ahmed M, Abubaker J, Balde V, Qadri Z, Ajarim D, Al-Dayel F, Hussain AR, Al-Kuraya KS (2011b) The biological and clinical impact of inhibition of NF-kappaB-initiated apoptosis in diffuse large B cell lymphoma (DLBCL). J Pathol 224: 355-366.

Beroukhim R, Mermel CH, Porter D, Wei G, Raychaudhuri S, Donovan J, Barretina J, Boehm JS, Dobson J, Urashima M, Mc Henry KT, Pinchback RM, Ligon AH, Cho YJ, Haery L, Greulich H, Reich M, Winckler W, Lawrence MS, Weir BA, Tanaka KE, Chiang DY, Bass AJ, Loo A, Hoffman C, Prensner J, Liefeld T, Gao Q, Yecies D, Signoretti S, Maher E, Kaye FJ, Sasaki H, Tepper JE, Fletcher JA, Tabernero J, Baselga J, Tsao MS, Demichelis F, Rubin MA, Janne PA, Daly MJ, Nucera C, Levine RL, Ebert BL, Gabriel S, Rustgi AK, Antonescu CR, Ladanyi M, Letai A, Garraway LA, Loda M, Beer DG, True LD, Okamoto A, Pomeroy SL, Singer S, Golub TR, Lander ES, Getz G, Sellers WR, Meyerson M (2010) The landscape of somatic copy-number alteration across human cancers. Nature 463: 899-905.

Blume-Jensen P, Hunter T (2001) Oncogenic kinase signalling. Nature 411: 355-365.

Boland CR, Thibodeau SN, Hamilton SR, Sidransky D, Eshleman JR, Burt RW, Meltzer SJ, Rodriguez-Bigas MA, Fodde R, Ranzani GN, Srivastava S (1998) A National Cancer Institute Workshop on microsatellite instability for cancer detection and familial predisposition: development of international criteria for the determination of microsatellite instability in colorectal cancer. Cancer Res 58: 5248-5257.

Bridge JA, Kanamori M, Ma Z, Pickering D, Hill DA, Lydiatt W, Lui MY, Colleoni GW, Antonescu CR, Ladanyi M, Morris SW (2001) Fusion of the ALK gene to the clathrin heavy chain gene, CLTC, in inflammatory myofibroblastic tumor. Am J Pathol 159: 411-415.

Camp RL, Dolled-Filhart M, Rimm DL (2004) X-tile: a new bio-informatics tool for biomarker assessment and outcome-based cut-point optimization. Clin Cancer Res 10: 7252-7259.

Carvalho B, Postma C, Mongera S, Hopmans E, Diskin S, Van De Wiel MA, Van Criekinge W, Thas O, Matthai A, Cuesta MA, Terhaar Sive Droste JS, Craanen M, Schrock E, Ylstra B, Meijer GA (2009) Multiple putative oncogenes at the chromosome $20 \mathrm{q}$ amplicon contribute to colorectal adenoma to carcinoma progression. Gut 58: 79-89.

Chen Y, Takita J, Choi YL, Kato M, Ohira M, Sanada M, Wang L, Soda M, Kikuchi A, Igarashi T, Nakagawara A, Hayashi Y, Mano H, Ogawa S (2008) Oncogenic mutations of ALK kinase in neuroblastoma. Nature 455: 971-974.

Corao DA, Biegel JA, Coffin CM, Barr FG, Wainwright LM, Ernst LM, Choi JK, Zhang PJ, Pawel BR (2009) ALK expression in rhabdomyosarcomas: correlation with histologic subtype and fusion status. Pediatr Dev Pathol 12: 275-283.

Debelenko LV, Arthur DC, Pack SD, Helman LJ, Schrump DS, Tsokos M (2003) Identification of CARS-ALK fusion in primary and metastatic lesions of an inflammatory myofibroblastic tumor. Lab Invest 83: 1255-1265.

Debelenko LV, Raimondi SC, Daw N, Shivakumar BR, Huang D, Nelson M, Bridge JA (2011) Renal cell carcinoma with novel VCL-ALK fusion: new representative of ALK-associated tumor spectrum. Mod Pathol 24: $430-442$.

Debiec-Rychter M, Marynen P, Hagemeijer A, Pauwels P (2003) ALK-ATIC fusion in urinary bladder inflammatory myofibroblastic tumor. Genes Chromosomes Cancer 38: 187-190.

Del Grosso F, De Mariano M, Passoni L, Luksch R, Tonini GP, Longo L (2011) Inhibition of N-linked glycosylation impairs ALK phosphorylation and disrupts pro-survival signaling in neuroblastoma cell lines. $B M C$ Cancer 11: 525.

Du XL, Hu H, Lin DC, Xia SH, Shen XM, Zhang Y, Luo ML, Feng YB, Cai Y, Xu X, Han YL, Zhan QM, Wang MR (2007) Proteomic profiling of proteins dysregulted in Chinese esophageal squamous cell carcinoma. J Mol Med 85: 863-875.

Gascoyne RD, Lamant L, Martin-Subero JI, Lestou VS, Harris NL, Muller-Hermelink HK, Seymour JF, Campbell LJ, Horsman DE, Auvigne I, Espinos E, Siebert R, Delsol G (2003) ALK-positive diffuse large B-cell lymphoma is associated with Clathrin-ALK rearrangements: report of 6 cases. Blood 102: 2568-2573.

George RE, Sanda T, Hanna M, Frohling S, Luther 2nd W, Zhang J, Ahn Y, Zhou W, London WB, McGrady P, Xue L, Zozulya S, Gregor VE, Webb TR, Gray NS, Gilliland DG, Diller L, Greulich H, Morris SW, Meyerson M, Look AT (2008) Activating mutations in ALK provide a therapeutic target in neuroblastoma. Nature 455: 975-978.

Grande E, Bolos MV, Arriola E (2011) Targeting oncogenic ALK: a promising strategy for cancer treatment. Mol Cancer Ther 10: 569-579.

Griffin CA, Hawkins AL, Dvorak C, Henkle C, Ellingham T, Perlman EJ (1999) Recurrent involvement of 2p23 in inflammatory myofibroblastic tumors. Cancer Res 59: 2776-2780.

Grob TJ, Heilenkotter U, Geist S, Paluchowski P, Wilke C, Jaenicke F, Quaas A, Wilczak W, Choschzick M, Sauter G, Lebeau A (2012) Rare oncogenic mutations of predictive markers for targeted therapy in triple-negative breast cancer. Breast Cancer Res Treat 134: 561-567.

Hernandez L, Pinyol M, Hernandez S, Bea S, Pulford K, Rosenwald A, Lamant L, Falini B, Ott G, Mason DY, Delsol G, Campo E (1999) TRK-fused gene (TFG) is a new partner of ALK in anaplastic large cell lymphoma producing two structurally different TFG-ALK translocations. Blood 94: 3265-3268.

Janoueix-Lerosey I, Lequin D, Brugieres L, Ribeiro A, De Pontual L, Combaret V, Raynal V, Puisieux A, Schleiermacher G, Pierron G, Valteau-Couanet D, Frebourg T, Michon J, Lyonnet S, Amiel J, Delattre O (2008) Somatic and germline activating mutations of the ALK kinase receptor in neuroblastoma. Nature 455: 967-970.

Jazii FR, Najafi Z, Malekzadeh R, Conrads TP, Ziaee AA, Abnet C, Yazdznbod M, Karkhane AA, Salekdeh GH (2006) Identification of squamous cell carcinoma associated proteins by proteomics and loss of beta tropomyosin expression in esophageal cancer. World J Gastroenterol 12: 7104-7112.

Jehan Z, Bavi P, Sultana M, Abubaker J, Bu R, Hussain A, Alsbeih G, Al-Sanea N, Abduljabbar A, Ashari LH, Alhomoud S, Al-Dayel F, Uddin S, Al-Kuraya KS (2009) Frequent PIK3CA gene amplification and its clinical significance in colorectal cancer. J Pathol 219: 337-346.

Jehan Z, Siraj AK, Abubaker J, Ruiz C, Simon R, Sultana M, Uddin S, Bavi P, Hussain A, Razack S, Ezzat A, Al-Dayel F, Sauter G, Al-Kuraya KS (2008) Distinct gene expression profiles: nodal versus extranodal diffuse large B-cell lymphoma. Oncology 75: 71-80.

Katayama R, Khan TM, Benes C, Lifshits E, Ebi H, Rivera VM, Shakespeare WC, Iafrate AJ, Engelman JA, Shaw AT (2011) Therapeutic strategies to overcome crizotinib resistance in non-small cell lung cancers harboring the fusion oncogene EML4-ALK. Proc Natl Acad Sci USA 108: 7535-7540.

Kelleher FC, McDermott R (2010) The emerging pathogenic and therapeutic importance of the anaplastic lymphoma kinase gene. Eur J Cancer 46: 2357-2368.

Kwak EL, Bang YJ, Camidge DR, Shaw AT, Solomon B, Maki RG, Ou SH, Dezube BJ, Janne PA, Costa DB, Varella-Garcia M, Kim WH, Lynch TJ, Fidias P, Stubbs H, Engelman JA, Sequist LV, Tan W, Gandhi L, Mino-Kenudson M, Wei GC, Shreeve SM, Ratain MJ, Settleman J, Christensen JG, Haber DA, Wilner K, Salgia R, Shapiro GI, Clark JW, Iafrate AJ (2010) Anaplastic lymphoma kinase inhibition in non-small-cell lung cancer. N Engl J Med 363: 1693-1703.

La Madrid AM, Campbell N, Smith S, Cohn SL, Salgia R (2012) Targeting ALK: a promising strategy for the treatment of non-small cell lung cancer, non-Hodgkin's lymphoma, and neuroblastoma. Target Oncol 7: 199-210.

Lamant L, Dastugue N, Pulford K, Delsol G, Mariame B (1999) A new fusion gene TPM3-ALK in anaplastic large cell lymphoma created by a (1;2)(q25;p23) translocation. Blood 93: 3088-3095.

Lamant L, Gascoyne RD, Duplantier MM, Armstrong F, Raghab A, Chhanabhai M, Rajcan-Separovic E, Raghab J, Delsol G, Espinos E (2003) Non-muscle myosin heavy chain (MYH9): a new partner fused to ALK in anaplastic large cell lymphoma. Genes Chromosomes Cancer 37: 427-432.

Lawrence B, Perez-Atayde A, Hibbard MK, Rubin BP, Dal Cin P, Pinkus JL, Pinkus GS, Xiao S, Yi ES, Fletcher CD, Fletcher JA (2000) TPM3-ALK and 
TPM4-ALK oncogenes in inflammatory myofibroblastic tumors. Am J Pathol 157: 377-384.

Lin E, Li L, Guan Y, Soriano R, Rivers CS, Mohan S, Pandita A, Tang J, Modrusan Z (2009) Exon array profiling detects EML4-ALK fusion in breast, colorectal, and non-small cell lung cancers. Mol Cancer Res 7: 1466-1476.

Lipson D, Capelletti M, Yelensky R, Otto G, Parker A, Jarosz M, Curran JA, Balasubramanian S, Bloom T, Brennan KW, Donahue A, Downing SR, Frampton GM, Garcia L, Juhn F, Mitchell KC, White E, White J, Zwirko Z, Peretz T, Nechushtan H, Soussan-Gutman L, Kim J, Sasaki H, Kim HR, Park SI, Ercan D, Sheehan CE, Ross JS, Cronin MT, Janne PA, Stephens PJ (2012) Identification of new ALK and RET gene fusions from colorectal and lung cancer biopsies. Nat Med 18: 382-384.

Ma Z, Hill DA, Collins MH, Morris SW, Sumegi J, Zhou M, Zuppan C, Bridge JA (2003) Fusion of ALK to the Ran-binding protein 2 (RANBP2) gene in inflammatory myofibroblastic tumor. Genes Chromosomes Cancer 37: 98-105.

Mino-Kenudson M, Chirieac LR, Law K, Hornick JL, Lindeman N, Mark EJ, Cohen DW, Johnson BE, Janne PA, Iafrate AJ, Rodig SJ (2010) A novel, highly sensitive antibody allows for the routine detection of ALK-rearranged lung adenocarcinomas by standard immunohistochemistry. Clin Cancer Res 16: 1561-1571.

Morris SW, Kirstein MN, Valentine MB, Dittmer KG, Shapiro DN, Saltman DL, Look AT (1994) Fusion of a kinase gene, ALK, to a nucleolar protein gene, NPM, in non-Hodgkin's lymphoma. Science 263: $1281-1284$.

Nitta H, Tsuta K, Yoshida A, Ho SN, Kelly BD, Murata LB, Kosmeder J, White K, Ehser S, Towne P, Schemp C, McElhinny A, Ranger-Moore J, Bieniarz C, Singh S, Tsuda H, Grogan TM (2013) New methods for ALK status diagnosis in non-small-cell lung cancer: an improved ALK immunohistochemical assay and a new, brightfield, dual ALK IHC-in situ hybridization assay. J Thorac Oncol 8: 1019-1031.

Palmer RH, Vernersson E, Grabbe C, Hallberg B (2009) Anaplastic lymphoma kinase: signalling in development and disease. Biochem $J \mathbf{4 2 0}$ 345-361.

Panagopoulos I, Nilsson T, Domanski HA, Isaksson M, Lindblom P, Mertens F, Mandahl N (2006) Fusion of the SEC31L1 and ALK genes in an inflammatory myofibroblastic tumor. Int J Cancer 118: 1181-1186.

Perez-Pinera P, Garcia-Suarez O, Menendez-Rodriguez P, Mortimer J, Chang Y, Astudillo A, Deuel TF (2007) The receptor protein tyrosine phosphatase (RPTP)beta/zeta is expressed in different subtypes of human breast cancer. Biochem Biophys Res Commun 362: 5-10.

Pfaffl MW, Horgan GW, Dempfle L (2002) Relative expression software tool (REST) for group-wise comparison and statistical analysis of relative expression results in real-time PCR. Nucleic Acids Res 30: e36.

Preusser M, Berghoff AS, Ilhan-Mutlu A, Magerle M, Dinhof C, Widhalm G, Dieckmann K, Marosi C, Wohrer A, Hackl M, Zochbauer-Muller S, von Deimling A, Schoppmann SF, Zielinski CC, Streubel B, Birner P (2013) ALK gene translocations and amplifications in brain metastases of nonsmall cell lung cancer. Lung Cancer 80(3): 278-283.

Rooney PH, Boonsong A, McKay JA, Marsh S, Stevenson DA, Murray GI, Curran S, Haites NE, Cassidy J, McLeod HL (2001) Colorectal cancer genomics: evidence for multiple genotypes which influence survival. Br J Cancer 85: 1492-1498.

Salido M, Pijuan L, Martinez-Aviles L, Galvan AB, Canadas I, Rovira A, Zanui M, Martinez A, Longaron R, Sole F, Serrano S, Bellosillo B, Wynes MW, Albanell J, Hirsch FR, Arriola E (2011) Increased ALK gene copy number and amplification are frequent in non-small cell lung cancer. $J$ Thorac Oncol 6: 21-27.

Schoppmann SF, Streubel B, Birner P (2013) Amplification but not translocation of anaplastic lymphoma kinase is a frequent event in oesophageal cancer. Eur J Cancer 49: 1876-1881.

Shinmura K, Kageyama S, Tao H, Bunai T, Suzuki M, Kamo T, Takamochi K, Suzuki K, Tanahashi M, Niwa H, Ogawa H, Sugimura H (2008) EML4ALK fusion transcripts, but no NPM-, TPM3-, CLTC-, ATIC-, or TFG-ALK fusion transcripts, in non-small cell lung carcinomas. Lung Cancer 61: 163-169.

Soda M, Choi YL, Enomoto M, Takada S, Yamashita Y, Ishikawa S, Fujiwara S, Watanabe H, Kurashina K, Hatanaka H, Bando M, Ohno S, Ishikawa Y, Aburatani H, Niki T, Sohara Y, Sugiyama Y, Mano H (2007) Identification of the transforming EML4-ALK fusion gene in non-smallcell lung cancer. Nature 448: 561-566.

Sugawara E, Togashi Y, Kuroda N, Sakata S, Hatano S, Asaka R, Yuasa T, Yonese J, Kitagawa M, Mano H, Ishikawa Y, Takeuchi K (2012) Identification of anaplastic lymphoma kinase fusions in renal cancer: large-scale immunohistochemical screening by the intercalated antibody-enhanced polymer method. Cancer 118: 4427-4436.

Sun JM, Choi YL, Won JK, Hirsch FR, Ahn JS, Ahn MJ, Park K (2012) A dramatic response to crizotinib in a non-small-cell lung cancer patient with IHC-positive and FISH-negative ALK. J Thorac Oncol 7: e36-e38.

Takagi D, Tatsumi Y, Yokochi T, Takatori A, Ohira M, Kamijo T, Kondo S, Fujii Y, Nakagawara A (2013) Novel adaptor protein Shf interacts with ALK receptor and negatively regulates its downstream signals in neuroblastoma. Cancer Sci 104: 563-572.

Takeuchi K, Choi YL, Togashi Y, Soda M, Hatano S, Inamura K, Takada S, Ueno T, Yamashita Y, Satoh Y, Okumura S, Nakagawa K, Ishikawa Y, Mano H (2009) KIF5B-ALK, a novel fusion oncokinase identified by an immunohistochemistry-based diagnostic system for ALK-positive lung cancer. Clin Cancer Res 15: 3143-3149.

Takeuchi K, Soda M, Togashi Y, Ota Y, Sekiguchi Y, Hatano S, Asaka R, Noguchi M, Mano H (2011) Identification of a novel fusion, SQSTM1ALK, in ALK-positive large B-cell lymphoma. Haematologica 96: 464-467.

Takeuchi K, Soda M, Togashi Y, Suzuki R, Sakata S, Hatano S, Asaka R, Hamanaka W, Ninomiya H, Uehara H, Lim Choi Y, Satoh Y, Okumura S, Nakagawa K, Mano H, Ishikawa Y (2012) RET, ROS1 and ALK fusions in lung cancer. Nat Med 18: 378-381.

Thunnissen E, Bubendorf L, Dietel M, Elmberger G, Kerr K, Lopez-Rios F, Moch H, Olszewski W, Pauwels P, Penault-Llorca F, Rossi G (2012) EML4-ALK testing in non-small cell carcinomas of the lung: a review with recommendations. Virchows Arch 461: 245-257.

Tuma RS (2012) ALK gene amplified in most inflammatory breast cancers. $J$ Natl Cancer Inst 104: 87-88.

van Gaal JC, Flucke UE, Roeffen MH, De Bont ES, Sleijfer S, MavinkurveGroothuis AM, Suurmeijer AJ, van der Graaf WT, Versleijen-Jonkers YM (2012) Anaplastic lymphoma kinase aberrations in rhabdomyosarcoma: clinical and prognostic implications. J Clin Oncol 30: 308-315.

This work is published under the standard license to publish agreement. After 12 months the work will become freely available and the license terms will switch to a Creative Commons AttributionNonCommercial-Share Alike 3.0 Unported License.

Supplementary Information accompanies this paper on British Journal of Cancer website (http://www.nature.com/bjc) 